\title{
A CRÍTICA DE MARX À INVERSÃO HEGELIANA DA IDEIA COMO SUJEITO E DO HOMEM E DE SUAS PRODUÇÕES COMO PREDICADOS
}

\author{
Eduardo Ferreira Chagas ${ }^{1}$
}

\begin{abstract}
Resumo:
Mostrar-se-á que não é a Ideia absoluta de Hegel, mas o sujeito humano como sujeito de si que é sujeito de suas ideias e de suas instituições, como a família, a sociedade civil e o Estado. Estabelecer-se-á a crítica de Marx a Hegel por ele ter tomado não o homem, mas a ideia como central, como sujeito, como princípio produtor, do qual tudo deriva. Em Hegel, a realidade efetiva é a ideia realizada, ideia essa que Marx a tem, ao invés, apenas como produto do espírito humano, como predicado do sujeito humano. Hegel toma o predicado (a ideia) como independente e o faz sujeito. A ideia hegeliana enquanto sujeito e elemento criador e regulador do mundo, princípio que gera tudo a partir de sua autodeterminação, se assemelha ao ser sobrenatural e sobre-humano (Deus) do Cristianismo, que, em vez de ser produto da criação humana, resultado da vontade imaginária, se converte no ser criador de tudo, do homem e da natureza, que, asssim privados de suas realidades materiais, de suas verdadeiras determinações, aparecem, pois, como manifestações, exteriorizações, da ideia, da atividade abstrata da Ideia Absoluta.
\end{abstract}

Palavras-chave: Marx. Sujeito-Predicado. Crítica de Marx a Hegel.

\section{MARX'S CRITICAL EVALUATION OF THE HEGELIAN INVERSION PROPOSITION OF IDEA AS SUBJECT, AND OF MAN AND HIS PRODUCTIONS AS PREDICATE}

\begin{abstract}
:
It will be manifested that it is not Hegel's Absolute Idea, but the human subject, as the subject of himself, who is the essence of his ideas and his institutions, such as family, civil society and State. Marx's critique of Hegel will be revealed because the philosopher took not man, but the idea as central, as subject, as a producing principle, from which everything derives. In Hegel, the effective reality is the realized idea, a proposition that Marx supports, instead, only as a product of the human spirit, as a predicate of the human subject. Hegel takes the predicate (the idea) as an independent item and makes it a subject. Idea, as proposed by Hegel, as a subject and a creative and regulating element of the world, a principle that generates everything from its self-determination, resembles the supernatural and superhuman being (God) of Christianity, who, instead of representing the product of human creation, results from an imaginary will, and becomes the creator of everything, of man and of nature, which, thus deprived of their material realities, of their true determinations, appear, therefore, as manifestations, or externalizations of being that arises from the abstract activity of the Absolute Idea.
\end{abstract}

Keywords: Marx. Subject-Predicate. Marx's Critique of Hegel.

1 Graduado em Filosofia pela Universidade Estadual do Ceará (UECE, 1989), Mestrado em Filosofia pela Faculdade de Filosofia e Ciências Humanas (FAFICH) da Universidade Federal de Minas Gerais (UFMG, 1993), Doutorado em Filosofia pela Universität von Kassel (KASSEL, ALEMANHA, 2002) e Pós-Doutorado em Filosofia pela Universität Munster (Alemanha) (2018-2019). É professor efetivo (associado) do Curso de Filosofia e do Programa de Pós-Graduação em Filosofia da Universidade Federal do Ceará (UFC) e professor colaborador do Programa de Pós-Graduação em Educação Brasileira da FACED - UFC. Coordenador do Grupo de Estudos Marxistas - GEM -, vinculado ao Eixo Marxismo, Teoria Crítica e Filosofia da Educação, e ao Programa de Pós-Graduação em Educação Brasileira da FACED - UFC. Orientador do Programa Jovens Talentos/CNPQ. Atualmente, é Pesquisador Bolsista de Produtividade do CNPQ, é membro da Internationale Gesellschaft der Feuerbach-Forscher (Sociedade Internacional Feuerbach) e dedica suas pesquisas ao estudo da filosofia política, da filosofia de Hegel, do idealismo alemão e de seus críticos Feuerbach, Marx, Adorno e Habermas. E-mail: ef.chagas@uol.com.br. Academia.edu: https://ufc.academia.edu/EduardoFChagas. Homepage: www.efchagas.wordpress.com. Editor da Revista Dialectus (http://periodicos.ufc.br/dialectus). C.V (Lates): http://lattes.cnpq.br/2479899457642563. ORCID: 0000-0003-1957-6117. 
A posição de Marx sobre a subjetividade detecta-se, inicialmente, a partir de sua inversão da inversão hegeliana entre sujeito e predicado, entre sujeito e atributo, tomando o homem como sujeito tanto das ideias quanto das instituições sociais, como a família, a sociedade civil e o Estado. Isto é evidente, em 1843, em sua obra Crítica da Filosofia do Direito de Hegel (Aus der Kritik der Hegelschen Rechtsphilosophie) $(1843)^{2}$, conhecida também como Contribuição à Crítica da Filosofia do Direito de Hegel, ou como a Crítica de Kreuznach, ou como Manuscritos de Kreuznach, ou, simplesmente, como Crítica de 1843, em que Marx crítica Hegel por ter, em sua obra Princípios da Filosofia do Direito (Grundlinien der Philosophie des Rechts) (1821), invertido os sujeitos em predicados, e os predicados em sujeitos, ou seja, por ter rebaixado o sujeito humano a sujeito posto por um outro ente (a ideia), tornando ele e todas as suas determinações meras efetivações da ideia abstrata. Apoiando-se em Feuerbach, para quem tanto a religião quanto a especulação filosófica inverteram a relação entre sujeito e predicado (na religião, Deus é o sujeito, o criador, e o homem é o predicado, a criatura; e, na especulação, a ideia é o sujeito, e as instituições são predicados) $)^{3}$, Marx defende que Hegel também inverte a

2 Essa obra, Crítica da Filosofia do Direito de Hegel (Aus der Kritik der Hegelschen Rechtsphilosophie) (1843), que permaneceu em Manuscrito, sem publicação na época de Marx, deixa de lado o Direito Abstrato, a Moralidade Subjetiva e as duas primeiras partes da Moralidade Objetiva, ou da Eticidade, a Família e a Sociedade Civil, da Filosofia do Direito, e se concentra na crítica à concepção hegeliano de Estado, particularmente a partir da crítica ao $\S 161$ da Filosofia do Direito, de Hegel. As quatro primeiras páginas, que se perderam, continham a crítica aos $\S 257, \S 258, \S 259$ e $\S 260$, que constituem o começo da análise do Estado e de suas instituições na Filosofia do Direito, de Hegel. Já a partir dessa obra, Marx, embora permanece fiel ao pensamento central de Hegel, se distância de Hegel e dos jovens hegelianos, ao não fazer culto ao Estado, ao negá-lo como uma organização política universal, racional; ao mostrar que o Estado, longe de ser uma esfera do interesse geral, determinante na formação, na organização e no desenvolvimento da sociedade, é, pelo contrário, determindado por essa sociedade, ou seja, que ele não é a encarnação da razão, nem uma mera forma mais elevada dos graus sucessivos de exteriorização, de determinação, da Moralidade Objetiva. Anos depois, em 1851, Marx se refere a essa obra nesses termos: "O primeiro trabalho que empreendi para dissipar as dúvidas que, então, me assaltavam, foi uma revisão crítica da Filosofia do Direito de Hegel, cuja introdução apareceu nos Anais Franco-Alemães, publicados em 1844, em Paris. A conclusão dessa crítica era que as instituições jurídicas e as diferentes formas de Estado não podem explicar-se por si mesmas ou por um suposto desenvolvimento do Espírito humano, mas que resultam das condições materiais de vida que Hegel, à imitação dos franceses e dos ingleses do século XVIII, designa com o nome de 'sociedade burguesa', cuja anatomina a dá a economia política”. Cf. Marx, K. Zur Kritik der politischen Ökonomie, p. 08.

3 Para Feuerbach, o homem é, na sociedade moderna, um ser fragmentado, separado de sua essência, e é, precisamente, essa separação que se explica o processo subjetivo da fé, da crença religiosa. Esta Feuerbach vê como um produto da subjetividade humana marcada pela cisão entre sua essência, o gênero, o universal, e sua existência singular, individual. Como o homem não pode efetivar, na sua existência singular, o gênero, o universal, ele o projeta para fora de si, num ser exterior a ele (= em Deus). Resulta daqui que o objeto (o homem) torna-se sujeito, e o sujeito (o gênero, Deus) torna-se objeto, pois não foi Deus que criou o homem, mas o homem quem criou subjetivamente Deus à sua imagem e semelhança. Mas, na religião, essa verdade antropológica não é evidente, pois o que aparece é uma inversão: Deus como sujeito (como criador), e o homem como predicado (como criatura). A pretensão de Feuerbach é inverter essa inversão e mostrar que a discórdia, a oposição, entre

\begin{tabular}{|l|l|l|l|l|}
\hline Qevista Dialectus & Ano 9 & n. 18 & Outubro 2020 & p. 219-234 \\
\hline
\end{tabular}


relação entre sujeito e predicado, fazendo, erradamente, da ideia o sujeito, e do homem e de suas instituições os predicados. Diante disto, Marx converte em sujeito o que Hegel julga predicado, e toma como predicado o que Hegel tem como sujeito. ${ }^{4}$ Precisamente, a crítica de Marx a Hegel é que este comete uma dupla inversão: primeiro, ele toma as instituições, como a família, a sociedade civil e o Estado, como meras objetivações, corporações, de uma ideia. Tais instituições são para Marx, ao contrário, universalidades concretas, comunidades reais, enquanto realizações, objetivações, não da ideia, mas do sujeito humano; tais instituições têm, pois, como pressuposto o sujeito humano. Este é "o ser de todos os seres"; as instituições, família, sociedade civil e Estado, são produzidas por ele, e nelas ele se objetiva. ${ }^{5}$ Segundo, Hegel inverte os sujeitos reais, a família e a sociedade civil, em atributos, em predicados abstratos da ideia de Estado. Entre essas instituições, Marx, em polêmica aqui com Hegel, precisa, por um lado, o caráter particular, privado e de classe da sociedade civil burguesa (bürgerliche Gesellschaft) e, por outro, toma-a como a verdadeira premissa, o sujeito, do Estado moderno, que não pode superar a partir de suas instâncias, como Hegel quer, as contradições, como a riqueza, a pobreza, a abundância, a excassez, a propriedade privada, isto é, os conflitos entre os interesse gerais e os particulares, da sociedade civil burguesa.

Em Hegel, particularmente, em sua supracitada obra "Princípios da Filosofia do Direito", a ideia da liberdade é central; ela é sujeito dela mesma e se desenvolve a partir dela mesma, de modo que a ideia da liberdade no Direito Abstrato, na Moralidade e nas esferas efetivas da Eticidade, a saber, na família, na sociedade civil e no Estado, são manifestações dela mesma. O Estado é a esfera ideal plena da liberdade, e a família e a sociedade civil são esferas ideais do Estado, reintegradas nele. Marx mostra, na sua já citada obra Crítica da Filosofia do

Deus (o divino, o sagrado) e o homem (o humano, o profano) é ilusória, porque o conteúdo da religião é inteiramente humano. Portanto, o homem só tomará consciência que Deus é uma projeção de sua subjetividade, de sua própria essência subjetiva, tomada de forma absoluta, quando converter a teologia em antropologia. Cf. CHAGAS, Eduardo F. "Religião: O homem como imagem de Deus ou Deus como imagem do homem." In: Formação Humana: Liberdade e Historicidade. Fortaleza: Edições UFC, 2004, Coleção Diálogos Intempestivos, v. 16. p. 86-105.

4 De forma semelhante diz Feuerbach em relação à filosofia especulativa de Hegel: "O método da crítica reformadora da filosofia especulativa não se distingue do que se empregou na Filosofia da Religião. Sempre estamos em condições de fazer do atributo o sujeito e deste o atributo; basta, pois, converter a filosofia especulativa para que a verdade se revele em toda sua pureza e claridade.“. Cf. Feuerbach, L. Teses Provisórias para a Reforma da Filosofia, p. 28.

5 Cf. MARTINS, Maurício Mello Vieira. Marx e o Sujeito Autônomo: Uma Polêmica. Dissertação de Mestrado, apresentada ao Departamento de Filosofia da PUC/RJ como parte dos requisitos para obtenção do título de Mestre em Filosofia. Rio de Janeiro, Departamento de Filosofia, PUC, mimeografado, 1990, p. 15-16.

\begin{tabular}{|l|l|l|l|l|}
\hline Qonista Dialectus & Ano 9 & n. 18 & Outubro 2020 & p. 219-234 \\
\hline
\end{tabular}


Direito de Hegel, que, em Hegel, o Estado é o sujeito, e a família e a sociedade civil são os predicados desse sujeito; ou, com outras palavras, o Estado é o pressuposto, e a família e a sociedade civil são os postos pelo Estado. Desta forma, Hegel trata a relação do Estado com a família e a sociedade civil de forma invertida, tendo o Estado como determinante, e a família e a sociedade civil como determinadas, pois, para ele, o Estado é a substância, a substância social, a identidade da diferença, a unidade da diversidade, o todo orgânico das partes, a esfera infinita, universal, geral, e é superior às partes, às esferas finitas dos interesses particulares da família e da sociedade civil, que dependem e estão subordinadas a ele (ao Estado). A relação da família e da sociedade civil com o Estado deixa transparecer, já aqui, segundo Marx, o "misticismo" especulativo de Hegel, quando ele toma a família e a sociedade civil como manifestações, fenômenos, atos da Ideia, da ideia subjetivada do Estado. "A ideia é subjetivada, e a relação efetiva da família e da sociedade civil burguesa com o Estado é concebida como sua atividade internar imaginada. (...) Mas, se a ideia é subjetivada, os sujeitos efetivos, sociedade civil burguesa, família, 'circunstâncias (...) etc.' transformam-se aqui em momentos objetivos da ideia, não efetivos, tendo um outro significado." ${ }^{” 6} \mathrm{Em}$ vez da família e da sociedade civil constituírem os pressupostos reais, materiais, do Estado, na especulação hegeliana surge o contrário: os sujeitos reais, a família e a sociedade civil, transformam-se em momentos "não reais", "em momentos" exteriorizados, objetivados, da "ideia"7. A família e a sociedade civil são "objetos da lógica" e não "lógicas do objeto", não são objetividades existentes a partir delas mesmas, mas determinações das idealidades (das categorias lógicas, dos conceitos, da ideia, da soberania, da vontade, do livre arbítrio, do "princípio da subjetividade", etc.), não são finitudes enquanto tais, mas finitudes da ideia; não são determinações próprias, mas determinações de um terceiro, da ideia, e têm o significado de um resultado místico, de um produto ideal, de uma obra ou determinação da ideia subjetivada. Diferentemente de Hegel, Marx deixa claro que o Estado não é um pressuposto autônomo, independente, pois ele não pode existir sem a base natural da família e sem a base material-econômica da sociedade civil. E enquanto Marx toma a família e a sociedade civil como as forças motrizes, como os pressupostos, como a conditio sine qua non do Estado, Hegel inverte essa relação e tem essa condição condicionante como sendo condicionada,

6 Marx, K. Aus der Kritik der Hegelschen Rechtsphilosophie - Kritik des Hegelschen Staatsrechts. In: Marx/Engels, Werke (MEGA), GW1. Berlin: Dietz Verlag, 1957, p. 206.

7 Ibdem, p. 206.

\begin{tabular}{|l|l|l|l|l|}
\hline Qevista Dialectus & Ano 9 & n. 18 & Outubro 2020 & p. 219-234 \\
\hline
\end{tabular}


o determinante como sendo o determinado, o pressuposto como posto, o produtor e criador (família e sociedade civil) como o produto de seu produto, o produto da criação do criado (do Estado). O Estado e os seus momentos materiais, a família e a sociedade civil, não são para Marx, como o são para a especulação hegeliana, uma obra, uma realização, da ideia subjetivada. Marx acredita que o segredo da filosofia hegeliana do direito se encontra expresso assim: "O fato, que serve como ponto de partida [a família e a sociedade civil], não é concebido como tal, mas sim como resultado místico [da ideia subjetivada do Estado]." ${ }^{8} \mathrm{O}$ que se pode deduzir disto é que Hegel toma aqui como sujeito a ideia subjetivada, a idealidade do Estado, a ideia mesma de Estado, e como predicado a família e a sociedade civil, ou seja, ele transforma sempre a ideia (o Estado) em sujeito e faz do sujeito real (a família e a sociedade civil) propriamente dito o predicado.

Nessa inversão do sujeito e do predicado, torna-se claro que o pressuposto, para Hegel, é a ideia tomada como sujeito, e o predicado são consequências, derivações, determinações, resultados, produtos, obras, da ideia. O ponto de partida é, pois, a ideia subjetivada, e seu desenvolvimento pleno, que é o Estado, considerado por Hegel como a ideia subjetivada que se torna plenamente objetiva enquanto organismo, totalidade orgânica, viva e racional. Hegel diz, precisamente, no $§ 267$ dos seus "Princípios da Filosofia do Direito", que a ideia ““(...) como substancialidade subjetiva (...) é o organismo do Estado, o Estado propriamente político e a sua Constituição." "9 $\mathrm{Na}$ idealidade hegeliana, o sujeito aqui é, como expresso, a ideia abstrata, a ideia lógica, "a ideia em si mesma", que é a "substância subjetiva" do Estado, que, como organismo, tem partes, diversos poderes, que não são fixos, mecânicos, inorgânicos, mas que se relacionam uns com os outros, que mantêm entre si relações dinâmicas, vivas e racionais. No § 269, diz Hegel que o Estado, “"este organismo, é o desenvolvimento [a transformação] da ideia em suas diferenças e em sua efetividade [realidade] objetiva. Esses lados distintos são assim os diferentes poderes com suas funções e atividades específicas através das quais o universal [a ideia] se produz de modo necessário e (...) se mantém"”. ${ }^{10}$ Tanto o Estado quanto seus poderes não são consequências de seus seres reais, determinados pelas suas próprias naturezas, mas sim por uma natureza estranha, quer dizer, pela natureza da ideia, e, assim sendo, são predicados,

8 Ibdem, p. 208.

9 Ibdem, p. 209.

${ }^{10}$ Ibdem, p. 209.

\begin{tabular}{|l|l|l|l|l|}
\hline Qevista Dialectus & Ano 9 & n. 18 & Outubro 2020 & p. 219-234 \\
\hline
\end{tabular}


determinações, da ideia, que é o "agens", o agente, o princípio determinante. Sendo objetos pensados, predicados da ideia, a realidade do Estado e de seus poderes não é real, material, concreta. No § 270, quando Hegel diz que “"o objetivo do Estado" é “"o interesse geral enquanto tal" e neste reside "“a conservação dos interesses particulares", ele deixa evidenciar a realidade genérica, abstrata, que o Estado aqui possui. Como Hegel parte da ideia como sujeito, da ideia como verdadeira realidade, o Estado universal, racional, e os seus poderes, enquanto produtos do desenvolvimento da ideia, adquirem, pois, um sentido lógico, formal, abstrato.

O Estado universal, orgânico, independente, que é, para Hegel, o sujeito e o fundamento da sociedade civil, se divide, ainda de acordo com Hegel, nos seguintes poderes: a) no poder legislativo, que tem a função de determinar e estabelecer o universal; b) no poder executivo, que tem o papel de integrar no universal os interesses particulares e singulares e c) no poder soberano (no poder do monarca), que representa, para Hegel, o poder da subjetividade como decisão da vontade, e é nesse poder que os outros poderes são agrupados numa unidade individual, constituindo uma totalidade entre eles. Marx analisa inicialmente o poder soberano, que se expressa em Hegel assim: “ $\$ 275$ - O poder soberano contém em si mesmo os três momentos da totalidade [(\$272)]: a universalidade da Constituição e das leis; a deliberação [execução], como relação do particular com o universal, e o momento da decisão final como autodeterminação (...). Este absoluto autodeterminar-se constitui o princípio distintivo do poder soberano enquanto tal" $" 11$. O poder do soberano, do monarca (da monarquia constitucional), expressa a universalidade da Constituição e das leis; ele visa vincular os interesses particulares aos interesses universais; ele é o poder de uma personalidade particular, de um sujeito, a saber, o poder do príncipe, que tem o poder da decisão final, como autodeterminação de sua vontade individual. Marx acredita ser um erro de Hegel fazer dos assuntos e das atividades do Estado e de seus poderes propriedade privada de uma personalidade particular, imediata, ou seja, reduzir a soberania do Estado, o poder soberano, a um sujeito, ao poder da subjetividade do soberano. Para Marx, os assuntos e as atividades do Estado estão ligados não a indivíduos físicos, particulares, isolados, mas a indivíduos político-sociais, na medida em que os indivíduos são membros do Estado, e este atua através daqueles. O Estado e suas atividades devem ser considerados, pois,

\footnotetext{
${ }^{11}$ Ibdem, p. 218.

\begin{tabular}{|l|l|l|l|l|}
\hline Qevista Dialectus & Ano 9 & n. 18 & Outubro 2020 & p. 219-234 \\
\hline
\end{tabular}
}


não como determinações de uma qualidade particular, física, de um indivíduo, mas como modos de existência das qualidades sociais dos homens.

A soberania do Estado, o poder soberano, tendo o seu fundamento, a sua base, o seu suporte, na subjetividade particular de um indivíduo, de um monarca, e não nas relações sociais, na unidade social dos indivíduos com o Estado, existe, então, só como subjetividade (que é uma transformação da ideia), como sujeito individual, expressando, com isto, uma ideia, um idealismo, de Estado, e não o Estado realmente existente. Sobre isto, frisa Hegel: ““ §279 - A soberania, primeiramente apenas o pensamento universal desta idealidade, existe somente como subjetividade certa de si mesma e como autodeterminação abstrata e, portanto, privada de fundamento, da vontade, na qual reside a decisão última [suprema]. É esta a individualidade do Estado enquanto tal, que só nele é uno. Mas apenas como sujeito, a subjetividade está em sua verdade (...). Este momento absolutamente decisivo do todo não é, por isto, a individualidade em geral, mas sim um indivíduo, o monarca." 12 Hegel toma como base do Estado não os sujeitos reais, sociais, mas a subjetividade particular como sujeito, pois, para ele, como a personalidade é uma pessoa, assim também a subjetividade é um predicado do sujeito, só existe como sujeito, ou melhor, é um sujeito. Isto constitui, na análise denunciadora de Marx, o caráter mistificador da Filosofia hegeliana do Direito, quer dizer, uma mistificação de Hegel, pois, em vez de a personalidade e a subjetividade serem predicados, determinações, da pessoa e do sujeito, elas (a personalidade e a subjetividade) se tornam independentes e se transformam em sujeitos. Nessas condições, a existência dos predicados (da personalidade e da subjetividade) é, em Hegel, o sujeito, de modo que o sujeito é a subjetividade, a existência da subjetividade independente, separada, do verdadeiro sujeito, do ser real, da realidade finita, da realidade do existente, que é, para Marx, o sujeito real, o sujeito do infinito, o suporte material, a base concreta, da subjetividade humana.

A soberania do Estado, o poder soberano, é, como mostrado, um indivíduo, um sujeito, a saber, o monarca, que é, para Hegel, uma "encarnação da ideia", da Razão. Mas a soberania é, diz Hegel ainda no $§ 279$, a "autodeterminação abstrata, porque sem fundamento, da vontade, na qual reside a decisão última [suprema]." ${ }^{13}$ Quer dizer, Hegel faz da autodeterminação da vontade, da decisão suprema da vontade, uma característica do soberano, do monarca, que

12 Ibdem, p. 223-224.

13 Ibdem, p. 224.

\begin{tabular}{|l|l|l|l|l|}
\hline Q Povista Qialectus & Ano 9 & n. 18 & Outubro 2020 & p. 219-234 \\
\hline
\end{tabular}


possui o poder soberano, a soberania, a decisão suprema, e é a encarnação exclusiva da personalidade do Estado, o sujeito do Estado, tal como a personalidade abstrata é o sujeito do Direito Abstrato. O poder soberano, o poder da decisão suprema, é constituído pela vontade livre (pelo eu quero $=1$ 'Etat c'est moi’) do monarca, e este é o aspecto individual do Estado, e só nele (no monarca) o Estado é uno (unidade) dos muitos unos, que compõe o povo. Mas, se a soberania do Estado existe no monarca, a soberania popular é antitética, oposta, a essa soberania que reside no monarca, uma vez que ela, para Hegel, é uma representação inculta do povo, uma totalidade confusa, genérica, uma abstração indeterminada. Tem-se aqui, segundo Marx, dois conceitos de soberania absolutamente opostos, residindo um no monarca e o outro no povo. Para Hegel, o povo, sem o soberano e sem a organização viva do Estado, "constitui a massa informe", "uma simples opinião geral", representada na república, na democracia. Frente ao poder absoluto do soberano, à monarquia, Marx defende a democracia (a plena, a verdadeira, democracia): nesta, diz ele, "nenhum momento recebe uma significação diferente daquela que lhe cabe. Cada momento é, efetivamente, apenas momento do demos inteiro. $\mathrm{Na}$ monarquia, uma parte determina o caráter do todo. A Constituição inteira tem de modificar-se de acordo com um ponto fixo. A democracia é o gênero da Constituição. A monarquia é uma espécie e, para dizer a verdade, uma má espécie."14 Marx vê a Constituição, na democracia, como obra, produto, livre do sujeito humano, como Constituição do povo, como uma determinação, a saber, como a autodeterminação do povo, que se refere à sua base real, ao sujeito humano real, ao povo real. Nessa diferença entre monarquia e democracia, Marx compara também a Constituição, na democracia, com a religião, tomando aqui como base a crítica de Feuerbach à religião, quando este tem a religião cristã como um produto da subjetividade humana: assim como a religião não produz o sujeito humano, mas é este quem cria a religião, assim também, diz Marx, a Constituição não produz o povo, mas é este quem cria a Constituição; quer dizer, o povo é o todo, o fundante, o poder constituinte, e a Constituição é a parte, o fundado, o poder constituído.

Nessa mesma linha de raciocínio, Marx toma, na democracia, não só a Constituição, a lei, mas também o Estado político como uma autodeterminação do sujeito humano, como um modo particular de existência do povo. Se na monarquia, e também na república política, enquanto forma particular do Estado, o universal (a lei, a Constituição, o Estado) está apartado do

14 Ibdem, p. 230-231.

\begin{tabular}{|l|l|l|l|l|}
\hline Gonista Dialectus & Ano 9 & n. 18 & Outubro 2020 & p. 219-234 \\
\hline
\end{tabular}


particular (da sociedade civil, da vida real dos sujeitos humanos), o homem político (o cidadão, o citoyen) separado do homem não-politico (do homem privado, do bourgeois), na verdadeira democracia há uma conciliação do Estado político com o não-político, uma unidade do universal (do Estado, da Constituição) com o particular (com a sociedade civil, com o sujeito humano real, concreto), ou, com outras palavras, o universal (o Estado) é uma determinação particular do sujeito, um conteúdo particular do povo, por isto, na verdadeira democracia, segundo Marx, o Estado político e a sociedade civil como instâncias autônomas, independentes do sujeito humano, tendem a desaparecer. É, precisamente, na modernidade, que a esfera política, o Estado político, aparece como a esfera celeste, universal, genérica, separada da esfera terrestre, da sociedade civil, da vida privada dos indivíduos humanos. Diz Marx, de forma enfática: “A abstração do Estado como tal pertence somente ao tempo moderno, porque a abstração da vida privada pertence só ao tempo moderno. A abstração do Estado político é um produto moderno." ${ }^{15}$ Diferentemente da modernidade, tanto no mundo antigo quanto no mundo medieval, a sociedade e o sujeito humano (o cidadão livre) eram políticos, pois, de fato, na Grécia antiga, a res publica era assunto privado, conteúdo real dos cidadãos, e o homem privado (livre) tinha o Estado político como instância pertencente à sua vida. Do mesmo modo, na Idade Média, as esferas privadas (as corporações de ofícios, de sábios, o comércio etc.) tinham um caráter político, eram também esferas políticas, isto é, não havia separação entre os interesses gerais e os interesses particulares, entre a vida pública e os assuntos privados, e estes, devido a isto, tinha um caráter sócio-político. Diferentemente do mundo antigo e medievo, na modernidade, o Estado político se torna uma realidade particular, apartada da sociedade civil e oposta à vida real dos indivíduos.

Anteriormente, vimos que a subjetividade (a subjetividade do Estado) é, para Hegel, o sujeito, e que esse sujeito é uma individualidade imediata, um indivíduo empírico, uno, a saber, o monarca, o soberano, que possui, na análise de Hegel, um conteúdo específico, uma determinação imediata, corporal, dada pelo nascimento natural, pela hereditariedade, e destinada à dignidade de monarca. Marx observa ironicamente, dizendo que, para Hegel, a naturalidade, a corporeidade, especifica a qualidade de um sujeito como soberano e determina a sua dignidade de monarca, de forma que, nesse raciocínio de Hegel, o momento da decisão suprema no Estado está ligado à natureza imediata, à animalidade, e não à razão. Na análise de Marx, há aqui em Hegel

15 Ibdem, p. 233.

\begin{tabular}{|l|l|l|l|l|}
\hline Qevista Dialectus & Ano 9 & n. 18 & Outubro 2020 & p. 219-234 \\
\hline
\end{tabular}


uma transição de conteúdo, uma conversão, através da qual Hegel passa da esfera da subjetividade (do sujeito do Estado, da soberania do Estado, da autodeterminação da vontade, da decisão suprema do monarca) para a da existência natural (para o corpo) do monarca. Sobre isto enfatiza Hegel no $\S 281$ dos seus "Princípios da Filosofia do Direito": “"Ambos os momentos [interno e externo, subjetividade e naturalidade] na sua unidade indivisível, o si mesmo último da vontade como ser supremo (...) e a existência (...), como determinação reservada à natureza, essa ideia (...) constitui majestade do monarca. Nesta unidade reside a unidade efetiva [real] do Estado""16. Marx afirma que a unidade real do Estado reside, neste sentido, em dois momentos arbitrários, em dois acasos: o acaso interno (subjetivo), o acaso da vontade pessoal do monarca, a subjetividade do soberano que decide em última instância, e o acaso externo (objetivo), o acaso da natureza, a soberania dada pelo nascimento, a soberania nascida. Uma consequência disto é que, em vez de o Estado ser uma realidade político-social, um modo de existência social do sujeito humano, é o poder soberano (a vontade particular, pessoal, subjetiva), enquanto subjetividade que decide em última instância, que se converte, na análise de Marx sobre Hegel, na soberania do Estado, ou seja, o subjetivo se converte em objetivo, ou, com outras palavras, é uma pessoa particular empírica, o monarca hereditário, que se converte na realidade suprema do Estado.

Hegel articula o poder soberano com o poder governamental (o poder executivo), uma vez que este tem como função, por um lado, aplicar, fazer cumprir, as resoluções daquele (do poder soberano) e, por outro, conservar o interesse geral, comum, no âmbito particular da família e da sociedade civil, ou seja, fazer com que os interesses particulares da família e da sociedade civil estejam subordinados aos interesses gerais do Estado. Sobre isto enfatiza Hegel no $§ 289$ dos seus "Princípios da Filosofia do Direito": “"A manutenção do interesse universal do Estado e da legalidade nesses direitos particulares e a condução destes àquele exige uma gestão da parte dos delegados do poder governamental, dos funcionários estatais executivos e superiores autoridades consultivas enquanto colegialmente constituídas, que convergem para as instâncias supremas que tocam o monarca." ${ }^{17}$ Hegel limita, assim, o poder governamental a uma função que é incluir o particular no geral, isto é, a uma tarefa que é governar a vida civil concretamente, ou, com outras palavras, conciliar os interesses particulares da sociedade civil

16 Ibdem, p. 237.

17 Ibdem, p. 243.

\begin{tabular}{|l|l|l|l|l|}
\hline Qenista Dialectus & Ano 9 & n. 18 & Outubro 2020 & p. 219-234 \\
\hline
\end{tabular}


burguesa, que é o campo de batalha de todos contra todos (hellum omnium contra omnes), com os interesses gerais do Estado. Essas funções do governo devem ser realizadas por indivíduos que são destinados a essas funções não pelas suas personalidades naturais ou pelos seus nascimentos, como o soberano, mas pelo reconhecimento de outros indivíduos acerca de suas capacidades subjetivas, de suas aptidões intelectivas. Mas, assim como o poder soberano - que é o poder que decide e é subjetivo, que depende da subjetividade do soberano -, o poder governamental é também subjetivo, e não objetivo, pois há aspectos contingentes, acidentais, subjetivos, tanto na capacidade dos funcionários do poder governamental quanto na escolha, na preferência, subjetiva, de uns entre muitos outros para ocuparem uma função no Estado, que é dirigir a coisa pública. Embora a capacidade e a escolha para ocupar uma função no Estado sejam subjetivas, o próprio Hegel chama a atenção, no § 294 dos "Princípios da Filosofia do Direito" e na nota desse parágrafo, também para o aspecto objetivo do poder governamental, na medida em que o indivíduo, por exercer um serviço público no Estado e por estar ligado ao universal, tem o dever de dar primazia ao geral, ao universal, sacrificando, assim, a satisfação pessoal de suas paixões, de seus interesses privados, de suas particularidades, de suas influências e pretensões subjetivas.

Hegel reduz, como expresso, o poder governamental a uma administração, que ele designa de burocracia, que tem como função, por um lado, impedir o exercício de um poder arbitrário e absoluto, estabelecendo um vínculo entre a monarquia e o povo, e, por outro lado, sujeitar o individual e o particular ao universal, quer dizer, administrar os interesses particulares da sociedade civil, para salvaguardar os interesses gerais, universais, genéricos, do Estado. "Na burocracia, a identidade do interesse do Estado e do fim particular privado está colocado de modo que o interesse do Estado se torna um fim privado particular contraposto aos demais fins privados." ${ }^{18}$ Hegel acredita que a superação da burocracia se daria, justamente, quando o interesse particular se sujeitasse ao universal, ou quando o particular se transformasse em interesse geral. O que Hegel quer é que as esferas da sociedade civil e seus interesses particulares estejam pela burocracia, pela administração, subordinados aos interesses superiores do Estado. ${ }^{19}$ Hegel parte do pressuposto que, na modernidade, o Estado e a sociedade civil são opostos, e que o Estado não tem um vínculo direto com a sociedade civil, mas se relaciona indiretamente com

18 Ibdem, p. 250.

19 Cf. Hegel, G F. W. Grundlinien der Philosophie des Rechts, in: Hauptwerke, sechs Bänden, Vol. 5, Darmstadt, Wissenschaftliche Buchgesellschaft, 1999, particularmente o $§ 289$.

\begin{tabular}{|c|c|c|c|c|}
\hline Qevista Dialectus & Ano 9 & n. 18 & Outubro 2020 & p. $219-234$ \\
\hline
\end{tabular}


ela através do poder governamental (da gestão administrativa, da burocracia, dos representantes do governo, dos funcionários do Estado ), que é encarregado, como expresso, de intervir no âmbito dela, para que os seus interesses privados não prevaleçam sobre os interesses comuns, coletivos. Com essa possibilidade de um cidadão poder se tornar mediante a burocracia um funcionário do Estado, Hegel pensa ter superado, superficialmente, a oposição entre a monarquia e o povo, entre o Estado e a sociedade civil, entre o Estado e a propriedade privada, sem pelo menos ter rejeitado a burocracia, que constiui uma casta especial de funcionários, uma corporação privilegiada, oposta ao conjunto da população, preocupada em defender, sobretudo, seus interesses particulares, não representando, portanto, o interesse geral. Marx denuncia que essa superação de Hegel da oposição entre o interesse geral e o interesse particular, entre o Estado e a sociedade civil através do poder governamental (dos representantes do Estado, da burocracia) é só aparente e serve, na verdade, para ocultar o caráter particular e reacionário da monarquia, pois ela constitui um simples arranjo, um reconhecimento legal, do próprio dualismo não resolvido.

Após as análises sobre os poderes soberano e governativo, Hegel fala sobre o poder legislativo, que faz parte da Constituição, mas existe anterior e fora dela, porque ele é o poder de organizar o geral, de elaborar, justamente, as leis da Constituição. O poder legislativo representa, pois, a generalidade, o interesse geral, o todo, a totalidade, em que atuam os outros dois poderes, o poder soberano, que é o poder da decisão suprema da subjetividade, e o poder governamental, que é o poder que aspira, conhece e executa o assunto geral. O problema é que esse interesse geral é, aqui, só subjetivo, formal, um universal só enquanto forma, a forma da universalidade, e não a universalidade como conteúdo; ele é uma ilusão dos assuntos do Estado como aparência dos assuntos do povo, ou seja, esse interesse geral é elaborado sem ter em conta, na verdade, o interesse real do povo, sem a intervenção do povo. Nos Princípios da Filosofia do Direito, de Hegel, o saber e a vontade das assembleias populares, o povo, a consciência comum, constitui, entretanto, a parte insignificante ou a que deve ser posta em suspeito, pois, em Hegel, o povo é reduzido à "multidão" atomística, representado como "massa" indiferenciada, informe, matéria amorfa, inorgânica, "expressão inorgânica do pensamento e da vontade", a parte desordenada, desorganizada, "que não sabe o que quer" e "que não possui um saber particular do geral". O povo, as assembleias populares não possuem um saber particular para o geral, são supérfluas para o cumprimento do interesse geral, pois elas não possuem, de acordo com Hegel, um

\begin{tabular}{|l|l|l|l|l|}
\hline Qevista Dialectus & Ano 9 & n. 18 & Outubro 2020 & p. 219-234 \\
\hline
\end{tabular}


conhecimento profundo, a ciência administrativa, que os funcionários do Estado possuem. O poder legislativo tem, pois, como conteúdo o universal, o assunto geral, mas que só aparentemente é assunto geral. Tal poder é a base para a ilusão geral do Estado constitucional, para a sua realidade formal, em que o interesse do Estado aparece formalmente como interesse real do povo. Trata-se aqui na verdade, segundo Marx, de uma mentira confirmada, legal, em que se afirma que "o Estado é o interesse do povo ou que o povo é o interesse do Estado." 20 Distintamente do seu significado real, enquanto órgão particular, protetor de interesses privados das classes hegemônicas, o Estado moderno, constitucional, orgânico, aparece, justamente, como esfera universal, garantidor da liberdade do povo e do bem-estar geral.

Como frisado anteriormente, na modernidade, o Estado se refere, sim, ao geral, mas a sociedade civil remete ao particular. Já na Idade Média, "a organização da sociedade civil era política e o Estado político era a sociedade civil, ainda não havia esta separação, esta duplicação" da diferença entre sociedade civil e Estado político. Estes "não significavam uma coisa no mundo social [civil] e outra no mundo político, (...) mas conferiam significados a si próprios [a si mesmas]. ${ }^{22}$ Diferentemente da sociedade medieval, em que havia, de certa maneira, uma síntese entre a sociedade e o Estado, uma identidade entre a sociedade civil e a sociedade política -, já que o princípio orgânico da sociedade civil era o princípio do Estado -, a sociedade moderna, a sociedade burguesa, da qual Hegel parte, se caracteriza pela busca e defesa não dos interesses gerais, mas exclusivamente dos interesses particulares, privados, e pressupõe a separação entre a vida privada e a vida pública, a vida política, concentrada no Estado, isto é, pressupõe a separação entre a sociedade civil burguesa (a vida civil) e o Estado político (a vida política), considerados, na verdade, não só como duas esferas separadas, mas diferentes e fundamentalmente opostas. A supressão plena do caráter político da sociedade civil, ou seja, a consolidação da separação entre a vida social e a vida política se deu com a Revolução Francesa. Como frisa Marx: "Foi a Revolução Francesa que consumou a transformação dos estamentos [das classes] políticos em estamentos [classes] sociais ou, por outras palavras, que fez das distinções estamentais [de classes] da sociedade civil em simples distinções [diferenças] sociais, distinções da vida privada, sem qualquer significado na vida política. A separação da vida política e da

${ }_{20}$ Marx, K. Aus der Kritik der Hegelschen Rechtsphilosophie - Kritik des Hegelschen Staatsrechts. Op. cit., p. 268.

21 Ibdem, p. 286.

22 Ibdem, p. 286.

\begin{tabular}{|l|l|l|l|l|}
\hline Ronista Dialectus & Ano 9 & n. 18 & Outubro 2020 & p. 219-234 \\
\hline
\end{tabular}


sociedade civil foi, assim, consumada." ${ }^{23}$ A sociedade civil é a não-realidade da existência da política, a esfera privada, particular, contingente, atomisticamente decomposta em indivíduos isolados, despojada do caráter político, carecida da atividade política, não tendo como fim o geral, mas o privado, daí ela é oposta ao Estado político, que é, por sua vez, uma esfera necessária, geral enquanto abstração dessa sociedade. Dessa separação da sociedade em sociedade civil e Estado político resulta, necessariamente, a separação do sujeito humano enquanto sujeito privado, membro burguês da sociedade civil, do sujeito cidadão, membro da cidadania política do Estado. Assim como o sujeito humano, na sociedade civil, é sujeito privado, fora do Estado, não toca o Estado político, assim também como o sujeito humano, no Estado, é sujeito público, cidadão, que tem uma existência puramente formal, abstraída da vida civil real. Diante dessa separação entre a vida civil e a vida política, os sujeitos têm uma existência fragmentada e contraditória, sendo "iguais" formalmente no céu do mundo político, mas continuando desiguais na existência terrestre da sociedade. Na sociedade civil, o sujeito aparece como sujeito isolado, como sujeito individual egoísta, circunscrito aos estreitos limites da sua esfera privada, fazendo da sua particularidade, da sua individualidade, a sua substância, o fim último; o sujeito real é o sujeito externo, separado do seu ser geral, privado da constituição do Estado, em que ele vale, em vez de sujeito isolado, como sujeito humano-social. Diante dessa separação e oposição do Estado político e da sociedade civil, Hegel não defende que o geral seja condicionado pelo particular, mas que o ser do Estado político (a generalidade) determine o ser da sociedade civil (a particularidade). Embora Hegel reconheça como consequência da sociedade moderna essa oposição entre a sociedade civil (a esfera dos interesses e das necessidades particulares) e o Estado político (a esfera geral, universal), ele não quer a separação entre a vida civil e a vida política, mas a unidade da vida civil e política no interior do Estado. Assim sendo, Hegel inverte a relação entre o sujeito e o predicado, fazendo do sujeito concreto, do determinante (a sociedade civil), o predicado, o determinado, e do predicado, do determinado (o Estado político), o sujeito abstrato, o determinante, ou seja, faz do Estado a causa do efeito (da sociedade civil), e do efeito a causa do Estado, cujo princípio é a ideia, a ideia absoluta como sujeito.

${ }^{23}$ Ibdem, p. 284.

\begin{tabular}{|l|l|l|l|l|}
\hline Qevista Dialectus & Ano 9 & n. 18 & Outubro 2020 & p. 219-234 \\
\hline
\end{tabular}




\section{REFERÊNCIAS:}

CHAGAS, Eduardo Ferreira; OLIVEIRA, Renato Almeida de. Consciência, Natureza e Crítica Social em Hegel, Feuerbach e Marx. Porto Alegre, RS: Editora FI, 2019, 305 p. ISBN: 978-855696-519-6. Disponível em: https://www.editorafi.org/519hegel.

CHAGAS, Eduardo F.; REDYSON, Deyve; PAULA, Marcio G. de. Homem e Natureza em Ludwig Feuerbach. Série Filosofia, nº 8, Fortaleza : Edições UFC, 2009.

CHAGAS, Eduardo F.; REDYSON, Deyve. Ludwig Fuerbach: filosofia, religião e natureza. São Leopoldo, Editora Nova Harmonia, 2011.

CHAGAS, Eduardo Ferreira. Natureza e Liberdade em Feuerbach e Marx. Campinas - SP: Editora Phi, 2016.

- O Pensamento de Marx sobre a Subjetividade. In: CHAGAS, Eduardo Ferreira/RECH, Hildemar Luiz/VASCONCELOS, Raquel/MATA, Vilson Aparecido da. Subjetividade e Educação. Fortaleza: Edições UFC, 2012.

. "O Método Dialético de Marx: investigação e exposição crítica do objeto." In:

Síntese - Revista de Filosofia. Belo Horizonte, v. 38, nº 120, 2011, p. 55-70.

"A natureza dúplice do trabalho em Marx: Trabalho útil-concreto e trabalho

abstrato.” In: Revista Outubro, no . 19, 2011, p. 61-80.

. "A crítica da política em Marx". In__: Trabalho,Filosofia e Educação no Espectro da Modernidade Tardia. Fortaleza: Edições UFC, 2007, p. 67-82.

1998.

A Comunidade Ilusória: A Teoria do Estado no Jovem Marx. Ijuí, Ed. UNIJUÍ,

"Religião: O homem como imagem de Deus ou Deus como imagem do homem."

In: Formação Humana: Liberdade e Historicidade. Fortaleza: Edições UFC, 2004, Coleção Diálogos Intempestivos, v. 16. p. 86-105.

. "Hegel e Marx: Crítica ao Caráter Formal-Abstrato dos Direitos Humanos", in:

Filosofia e Direitos Humanos, Fortaleza, Editora UFC, 2006, v. 4, p. 249-268.

ENGELS, F. Einleitung zu "Die Klassenkämpfe in Frankreich 1848 bis 1850" von Karl Marx, in: Marx/Engels Werke (MEGA),Berlin, Dietz Verlag, 1960, v. 7.

FEUERBACH, L. Teses Provisórias para a Reforma da Filosofia. Lisboa: Edições 70, 1988.

HEGEL, F. Grundlinien der Philosophie des Rechts, in: Hauptwerke in sechs Bänden, Darmstadt, Wissenschaftliche Buchgesellschaft, 1999, v. 5.

\begin{tabular}{|l|l|l|l|l|}
\hline Q Povista Qialectus & Ano 9 & n. 18 & Outubro 2020 & p. 219-234 \\
\hline
\end{tabular}


MARTINS, Maurício Mello Vieira. Marx e o Sujeito Autônomo: Uma Polêmica. Dissertação de Mestrado, apresentada ao Departamento de Filosofia da PUC/RJ como parte dos requisitos para obtenção do título de Mestre em Filosofia. Rio de Janeiro, Departamento de Filosofia, PUC, mimeografado, 1990.

MARX, K. Aus der Kritik der Hegelschen Rechtsphilosophie - Kritik des Hegelschen Staatsrechts. In: Marx/Engels, Werke (MEGA), GW1. Berlin: Dietz Verlag, 1957.

. Zur Kritik der hegelschen Rechtsphilosophie. Einleitung. In: MARX/ENGELS, Werke (MEGA). Berlin: Dietz Verlag, 1957, v. 1.

Zur Kritik der Politischen Ökonomie. in: Marx/Engels Werke (MEGA),Berlin, Dietz Verlag, 1961, v. 13.

. Zur Judenfrage, in: Marx/Engels Werke (MEGA),Berlin, Dietz Verlag, 1957, v. 1.

Verlag, 1958, v. 3.

Die deutsche Ideologie. In: MARX/ENGELS, Werke (MEGA). Berlin: Dietz

Kritische Randglossen zu dem Artikel "Der König von Preussen und die Sozialreform. Von einem Preussen", in: Marx/Engels Werke (MEGA),Berlin, Dietz Verlag, 1957, v. 1.

Die Klassenkämpfe in Frankreich 1848 bis 1850, in: Marx/Engels Werke (MEGA),Berlin, Dietz Verlag, 1960, v. 7.

. Kritik des Gothaer Programms. in: Marx/Engels Werke (MEGA),Berlin, Dietz Verlag, 1962, v. 19.

Vorwort zur Kritik der politischen Ökonomie. In: MARX/ENGELS, Werke (MEGA). Berlin: Dietz Verlag, 1983, v. 13.

SILVEIRA, Maria Lídia Souza da. Algumas notas sobre a temática da subjetividade no âmbito do marxismo.In: Revista Outubro, No. 7, 2002, p. 103.

\begin{tabular}{|l|l|l|l|l|}
\hline Revista Dialectus & Ano 9 & n. 18 & Outubro 2020 & p. 219-234 \\
\hline
\end{tabular}

